\section{FAUNA OF PROTECT AREAS - 7 A PRELIMINARY REPORT ON SPIDERS IN DESERT NATIONAL PARK, RAJASTHAN, INDIA}

\section{Sivaperuman* and N.S. Rathore}

Desert Regional Station, Zoological Survey of India, Pali Road, Jhalamand, Jodhpur, Rajasthan 342005, India

Email:*c_sivaperuman@hotmail.com

Biogeographically, the Great Indian or the Thar Desert is the easternmost edge of the Sahara-Arabian Desert zone with the highest human population density covering an area of approximately 2,80,000 $\mathrm{km}^{2}$ (Sekhar, 1998). The Thar Desert in is unique and is the only habitat of its type in the Indian subcontinent; the extremely hot region of the country exhibits vivid and spectacular biodiversity. The abundance of certain insects, mites, arachnids, centipedes, millipedes, amphibians, reptiles, birds and mammals speaks of the highly specialized deserticolous adaptations. Although some studies have been undertaken in the Thar Desert (Roonwal, 1982; Rathore, 1984; Rahmani, 1989; Prakash et al., 1992), very little information exists on spiders.

The Desert National Park (DNP) $\left(25^{\circ} 47^{\prime} \& 75^{0} 15^{\prime}-70^{\circ} 45 \mathrm{E}\right)$ is the proposed Desert Biosphere Reserve (DBR) (Figs. 1 \& 2) which is about $3,162 \mathrm{~km}^{2}$ with $1,900 \mathrm{~km}^{2}$ in Jaisalmer District and the remaining $1,262 \mathrm{~km}^{2}$ in Barmer District of Rajasthan. The area falls in the extreme hot, arid region of very low rainfall zone of the country. The human population is low at $4-5$ persons $/ \mathrm{km}^{2}$. The climate of this region is characterised by extremes of temperature. During summer the temperature rises up to $49^{\circ} \mathrm{C}$, sometimes touching $50^{\circ} \mathrm{C}$. The nights are generally very cool. The temperature in winter may fall down to $2^{\circ} \mathrm{C}$. The rainfall pattern is extremely erratic and annual rainfall is about 100 $150 \mathrm{~mm}$, but it rains only for about 3-7 days and mostly during the months of July-September.

The entire area is essentially plain grassland with few hills in the northwestern side of DNP. Sand hills and sand dunes dominate the entire zone. Most of the dunes are of Barchan types but tall fixed and parallel dunes are also present. These dunes, at places, rise up to $100 \mathrm{~m}$ elevation. In many places the desert consists of gravel, bare rock, sun-baked mud and loam. The latter form the bulk of the soil of this region. The major area consists of sandy plains.

Vegetation: Despite environmental limitations, some parts of the DNP appear as vast expanses of grassland intermixed with shrubs and small trees. Pandey et al. (1985) have reported 168 species of vascular plants belonging to 111 genera under 45 families from DNP. Lasiurus sindicus is the most important grass occupying $80 \%$ of the grassland community (Sekhar, 1998). Some of the important grasses are Dactyloctenium scindicum, Aristida sp. and Orpetium thomaeum. Dominant trees and shrubs are Prosopis cineraria (Khajam), Halorxylon salicornicum (Lana), Calligonum polygonoides (Phog), Capparis deciduas (Karil), Aerva pseudotomentosa (Sinia), Calotropis procera (Aak), and Saluadora oleoides (Jar).

The study was conducted in Desert National Park (DNP) Jaisalmer and Barmer District, Rajasthan from 1994 to 1998. A thorough search was made in different types of vegetation, sand dunes and other habitats. Collections were made by hand picking or directly into the specimen tubes/jars and preserved in $70 \%$ alcohol. The spiders were identified with the help of standard key of systematic references (Pocock, 1900; Subramanyam, 1968, 1969; Tikader, 1980, 1982; Tikader \& Biswas, 1981; Vijayalakshmi \& Ahimaz, 1993) and with an ordinary hand lens and microscope.

A total of 28 species of spiders belonging to 13 families and 21 genera (Table. 1) were recorded in Desert National Park. Among these, five species - Lycosa madani, Uroctea indica, Drassodes parvidens, Zelotes desioi and Drassodes luridus were new records for this area. Most of the spiders were non weavers. Neoscona sp., Herennia ornatissima, Stegodyphus sarasinorum were the only weavers. Highest number of genera and species were recorded in Lycosidae and Gnapohsidae followed by Thomisidae and Clubionidae.

The results of the present study shows that great variety of spiders exist in DNP. Among the recorded species, Stegodyphus sarasinorum, Hereropoda fabrei, Herennia ornatissima, Zelotes desioi were recorded only from Jaisalmer District. Other species were observed in both the districts.

\section{REFERENCES}

Pandey, R.P., B.V. Shetty and M.P. Verma (1985). A checklist to the flora of the Desert National Park in Western Rajasthan. Journal of Economic and Taxonomic Botany 6(1): 45-65.

Pocock, R.I. (1990). Fauna of British India, Arachnida, pp. 153-205. London.

Prakash, I., S.K. Saxena, P.K. Ghosh and H.C. Bohra (1992).

Table 1. List of spiders recorded in Desert National Park

\begin{tabular}{|c|c|}
\hline Scientific name & Scientific name \\
\hline $\begin{array}{l}\text { Lycosidae } \\
\text { Lycosa madani Pocock* }\end{array}$ & $\frac{\text { Sparassidae }}{\text { Sparassus sp.* }}$ \\
\hline $\begin{array}{l}\text { Lycosa sp.* } \\
\text { Pardosa sumatrana (Thorell) } \\
\text { Pardosa heterophthalma (Simon)* } \\
\text { Pardosa pusiola }(\text { Thorell)* } \\
\text { Pardosa sp.* } \\
\text { Hippasa sp.* }\end{array}$ & $\begin{array}{l}\text { Gnaphosidae } \\
\text { Zelotes nasikensis Tikader \& Gajbe } \\
\text { Zelotes desioi Caporiacco* } \\
\text { Poecilochroa sedula (Simon) * } \\
\text { Poecilochroa sp. } \\
\text { Drassodes parvidens Caporiacco* }\end{array}$ \\
\hline$\frac{\text { Araneidae }}{\text { Neoscona sp. }}{ }^{*}$ & $\begin{array}{l}\text { Drassodes luridus (O.P. Cambridge) } \\
\text { Gnaphosa sp.** }\end{array}$ \\
\hline Herennia ornatissima (Dol.)* & Oecobiidae \\
\hline Thomisidae & Uroctea indica Pocock* \\
\hline $\begin{array}{l}\text { Ozyptila chandosiensis Tikader* } \\
\text { Synaema sp.* }\end{array}$ & $\frac{\text { Corinnidae }}{\text { Aetius sp. }}$ \\
\hline Philodromidae & Castianeria sp.* \\
\hline Tibellus sp. ${ }^{*}$ & Miturgidae \\
\hline $\begin{array}{l}\text { Heteropodidae } \\
\text { Heteropoda fabrei Simon* }\end{array}$ & $\begin{array}{l}\text { Cheiracanthium sp.* } \\
\text { Oxyopidae }\end{array}$ \\
\hline $\begin{array}{l}\text { Erisidae } \\
\text { Stegodyphus sarasinorum Karch* }\end{array}$ & $\frac{\text { Oxyopidae }}{\text { Peucetia sp. }}$ \\
\hline & ${ }^{*}$ - Female; ${ }^{* *}$ - male \\
\hline
\end{tabular}

Marpissa sp. . 


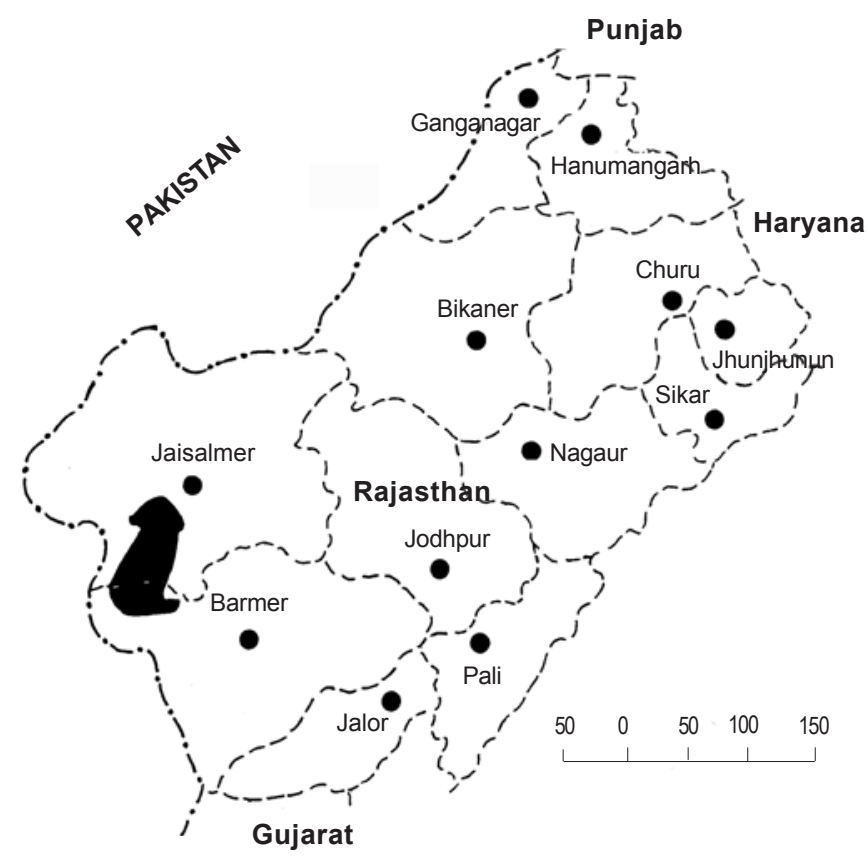

Fig. 1. Map of Western Rajasthan showing proposed area of the Thar Desert Biosphere Reserve

Vegetation and Wildlife in Thar, pp. 98-109. In: Kar, A., Abihichandani, K. Anantharaman and D.C. Joshi (Editors). Perspectives of the Thar and Karakum. Department Science and Technology, Govt. of India, New Delhi:

Rahmani, A.R. (1989). The uncertain future of the Desert National Park in Rajasthan, India. Environmental Conservation 16(3): 237-244. Rathore, N.S. (1984). Biological observations on Indian Desert termite Microtermes mycophagus (Termitidae). Oikoassay (1\&2): 5-10.

Roonwal, M.L. (1982). Fauna of the Great Indian Desert (past and present composition, zoogeography, ecology, biology, physiology and conservation). In: Singh, A. (Editor). Desert Resources and Technology, 1: 1-86. Scientific Publishers \& Geo-Tech Academy, Jodhpur.

Sekhar, U.N. (1998). Ecological status of the Desert National Park past and present. Tigerpaper 25(2): 14-18.

Subramanyam, T.V. (1968). An introduction to the study of Indian Spiders (part I). Journal of the Bombay Natural History Society 62(2): 453-462.

Subramanyam, T.V. (1969). An introduction to the study on Indian Spiders (part II). Journal of the Bombay Natural History Society 65(3): 726-743

Tikader, B.K. (1980). Fauna of India. Spiders Vol. I. Araneae (Thomsidae \& Lycosidae) Zoological Survey of India, Calcutta.

Tikader, B.K. (1982). Fauna of India. Spiders Vol. II Araneae (Araneidae and Gnophosidae). Zoological Survey of India, Calcutta.

Tikader, B.K. and B. Biswas (1981). Spider fauna of Calcutta and its vicinity part I. Records of the Zoological Survey India. Paper No. 30: $1-149$.

Vijalakshmi, K. and P. Ahimaz (1993). Spiders an Introduction. Cre: A. Madras, $112 \mathrm{pp}$.

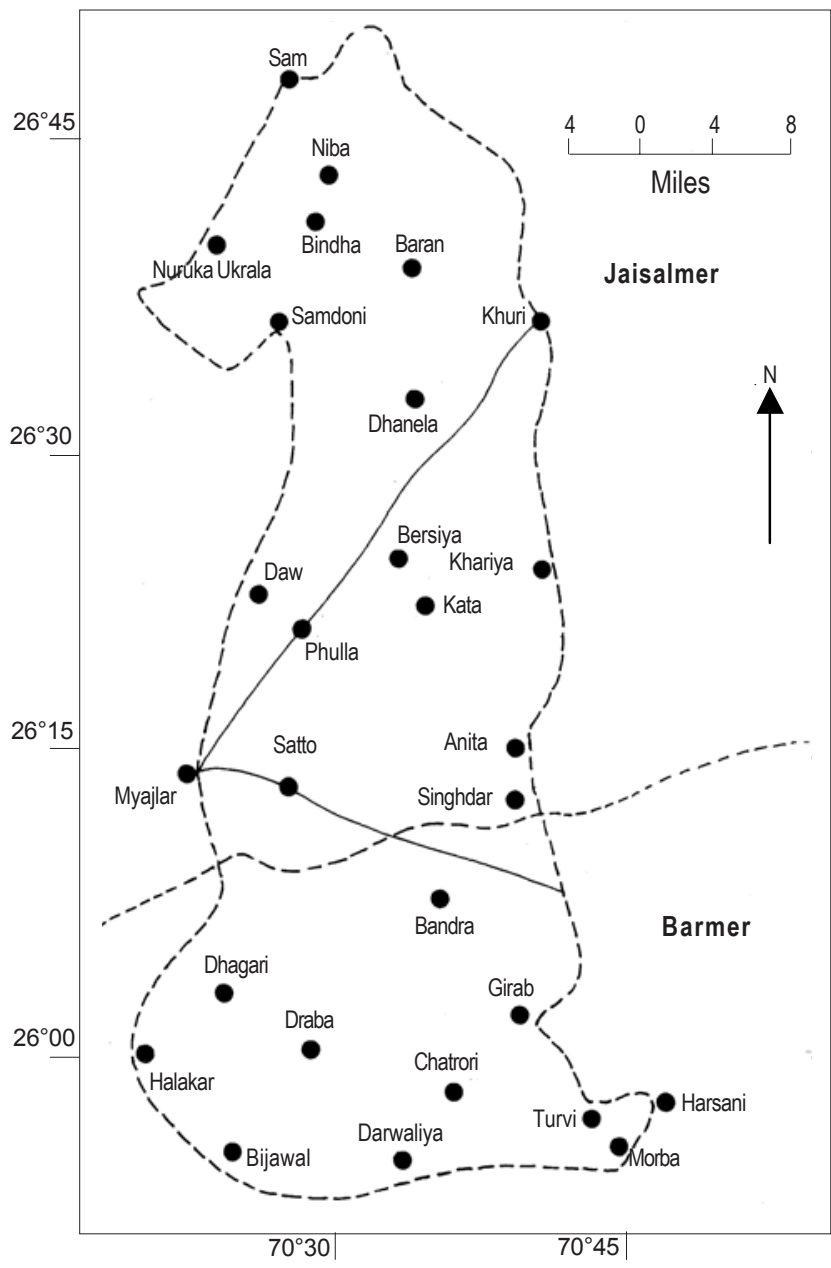

Figure 2. Desert National Park Area covering the proposed Thar Desert Biosphere Reserve

\section{ACKnowledgements}

The authors acknowledge the Director, Zoological Survey of India, Kolkata and Officer-in-Charge, Desert Regional Station, Zoological Survey of India, Jodhpur for providing necessary facilities and encouragement for this study. Thanks are also due to Dr. B. Biswas, Scientist, Zoological Survey of India, Kolkata for identifying the spiders, and Director-in-charge, Desert National Park, Jaisalmer for co-operation and help in carrying out the field surveys in DNP. 